\title{
中枢神経系に対する理学療法アプローチ \\ 一課題指向型アプローチからMotor Relearning Programへ— \\ Physical Therapy Approaches for the Central Nervous System: \\ From the Task-Oriented Approach to the Motor Relearning Program
}

\section{藤田 博曉1) 潮見 泰藏 $\left.{ }^{2}\right)$}

HIROAKI FUJITA, PT, $\mathrm{PhD}^{1)}$, TAIZO SHIOMI, PT, $\mathrm{PhD}^{2)}$

1) Department of Physical Therapy, Faculty of Health and Medical Care, Saitama Medical University: 981 Kawakado, Moroyama, Saitama 350-0496, Japan. TEL 81+49-295-1001

2) Department of Physical Therapy, International University of Health and Welfare

Rigakuryoho Kagaku 22(3): 319-324, 2007. Submitted May 18, 2007.

ABSTRACT: In this paper we give an account of the development of physical therapy and discuss the motor relearning program and the task-oriented approach as new physical therapy interventions. Physical therapy intervention for the central nervous system focusing on stroke, should aim not just to improve paralysis, as therapy focused on the practical aspects of daily living is being requested.

Key words: physical therapy model, task-oriented approach, motor relearning program

要旨: 本稿では, 理学療法モデルの変遷を述べ, 新たな理学療法介入として「課題指向型アプローチ」, 「Motor Relearning Program」について論じた。脳卒中を中心とする中枢神経系の理学療法介入は, 単に麻痺の改善を目的とするだけでな く, 生活を見据えた実践的な治療が求められている。 キーワード : 理学療法理論, 課題指向型アプローチ, Motor Relearning Program

1) 埼玉医科大学 保健医療学部理学療法学科：埼玉県入間郡毛呂山町川角981（テ350-0496） TEL 049-295-1001

2) 国際医療福祉大学 保健医療学部理学療法学科

受付日 2007年5月18日 


\section{I.はじめに}

わが国に理学療法士が誕生して40年を超える歷史の 中で, 脳卒中を中心とする中枢神経系障害はその主要な 対象疾患である。1995年の理学療法白書1)によると, 主 たる理学療法の対象疾患のなかで脳卒中は $10 \%$ 超えて おり,多くの施設において対象の半数を占めているとい われている。われわれ理学療法士はこのような中枢神経 系障害の患者を長く治療対象としてきた。しかし，その 治療理論や治療内容について統一した意見は見られて おらず, 旧態依然として手探りの状態で行われている現 状にある。2004に策定された「脳卒中治療ガイドライン 2004, 脳卒中合同ガイドライン委員会」2)においても, 運動障害に対するリハビリテーションとして早期から 集中的に行うことの必要性は述心らられている。しかし, 具体的な治療理論や治療手段についての一致した意見 は得られていない。

1990年代後半から2000年前半にかけて, 脳科学の進歩 により脳損傷後の機能回復と大脳皮質可塑性について 多くの研究成果が得られている。理学療法分野において も徐々にではあるが新しい研究成果が取り入れられて いる。また, 米国理学療法協会主催によるSTEP (Special Therapeutic Exercise Project）に代表されるように，現在 の理学療法理論は大きく見直されており,治療理論には 「運動学習理論」や「運動制御理論」が導入されている。

本稿では中枢神経疾患に対する理学療法理論の変遷 を概観し, 運動学習理論に基づく「Motor Relearning Program」ならびに「課題指向型アプローチ」による理 学療法介入について述べることにする。

\section{II. 理学療法理論の変遷 (STEP)}

中枢神経疾患に対する運動療法の理論に関する変遷 は, 米国理学療法協会 (APTA : American Physical Therapy Association）が開催した3つの会議による議論から見る ことができる3)。

1966年に米国のChicagoにおいてNU-STEP (Northwestern University Special Therapeutic Exercise Project）が開催され た。会議の目的は神経系の障害に対して個々の理学療法 士が各自の理論と技術で行っている現状に対して,その 相互理解を図る必要があるのではないかという声が発 端であった。この会議では(1)神経生理学, (2)運動発達, (3)運動学習, (4)運動制御の4つのテーマについて議論が 行われた。特に, この会議ではいわゆるSpecial Technique といわれる6つ (Bobath, Brnnstrome, PNF, Temple Fay,

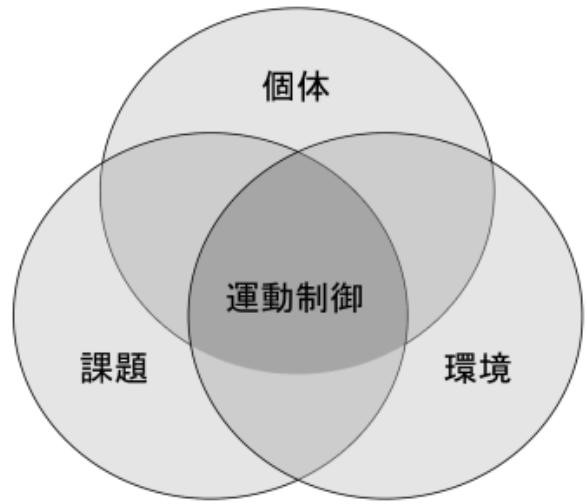

図1 システム理論

運動行動は, 運動制御に必要な様々な側面に 関係する多くのシステムが同一平面上に位置 し, その相互作用や力動関係により生じる (Bernstein, 1932)

Rood，Winthrop Phelps）について技術講習や議論が行わ れ, その共通性や独自性についての相互理解が図られて いる。また, 理学療法治療技術の枠組みとして, 神経系 の構造は機能を規定するものであるといわれ，「セラピ ストのハンドリングによって運動（機能）をコントロー ルすることで脳を治療できる」と考えられ，この考え方 の内容は1980年代までの教科書としても利用されてい た。しかし，NU-STEPから数年後にはSpecial Technique の治療効果に対する疑問符が投げ掛けられることとなっ た。

1990年にはOklahomaにおいてIISTEPが開催された。こ のIISTEPでは生態学理論やシステム理論が提唱され, 中 枢神経系機能の理論体系が著しく変化することとなっ た。特に，1932年にBernsteinが提唱し1967年にその論文 集が英訳された「システム理論」は大きな注目を集める こととなった。この理論では,「人間の運動や行動は何 等かの課題を遂行している状態であって, その課題の達 成のためにはいくつかのシステムが動員されたり, 組織 化されたりした結果，ある行動パターンが生ずる」とい う考えから,個体と環境との相互作用による運動制御理 論を提案している。特に, 運動行動が単に末梢や中枢か ら一方的におこるのではなく, 中枢神経系を環境に適応 する自己調整システムとしてとらえている。つまり, 運 動行動に関わるシステムには, 比較システム, 命令シス テム, 調整システム, 感覚運動システムだけでなく, 中 枢神経外の筋骨格系システムや環境システムまでもが 含まれること。つまり, 個人一課題一環境の3者の相互 作用が運動制御を決定することという意見である。（図 
理学療法モデル

1940-1960年代

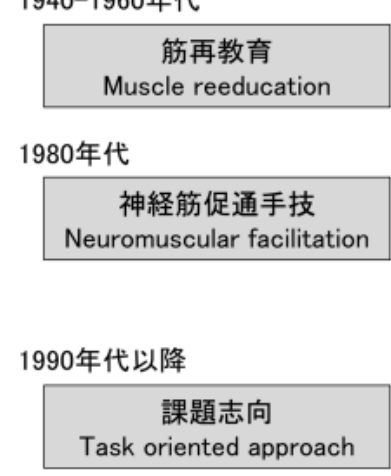

背景となる運動·制御理論

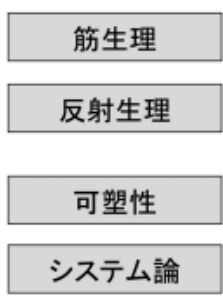

介入の基本概念

過負荷の原則

抑制と促通

運動学習

図2＼cjkstart理学療法モデルの変遷（内山 靖, 2004）

1）これを機として米国ではSpecial Techniqueに代表され る神経生理学的アプローチを主体とした理学療法は大 きな転換期を迎えることとなった。

また，2005年，Salt Lakeにおいて15年ぶりに開催され たIIISTEP Conferenceでは, IISTEPにおいて提案された理 論を臨床の場で実証し, 理論と教育・臨床を統合するこ とを目的として行われた。会議では小児から成人まで多 岐にわたった内容が議論され, 発表も豊富であった。な お, この内容は2007年APTAより討議内容が冊子として 発刊される予定である。

以上, 中枢神経系の理学療法理論の変遷をみても, わ が国の理学療法体系は米国のそれと比べて遅れている ことは否めない。その原因は本来なされるべきパラダイ ムの転換がなされていないことに加えて, 標準化された 測定指標（outcome measures）を用いた効果判定がなさ れていないことなどがあげられる4)。現代の理学療法 介入は, 単なる訓練や促通手技を行うことではなく, 運 動コントロールの再学習へと変化していることを確認 しておく必要がある。

このような理学療法モデルの変遷について, 内山は 対象者のニーズや理論的背景の発達によって変遷と拡 大を遂げていると述べている (図2 $)^{5,6}$ )。筋再教育 (muscle reeducation) を中心とした1960年代の理論から, 神経筋 促通手技 (neuromuscular facilitation/neurodevelopment approach）の1980年代の治療概念を経て, 現在では課題 指向型アプローチ（task oriented approach）やMotor Relearning Programが主流となっている。

\section{III. 課題指向型アプローチの概念と評価の視点}

課題指向型アプローチにおける仮説は, 神経促通法 の基礎となる仮説とはまったく異なる。課題指向型アプ ローチにおいては, 正常な運動は制御のさまざまな状況 に独自に寄与している多システム間の相互作用として 出現する。さらに, 運動は行動目標を中心として組織化 され，環境によって制約されるといわれている7,8)。特 に，正常な運動パターンを繰り返し練習することより も, 一つの日常的な運動課題に着目し, その運動課題に 特有な問題の解決を試みて, 課題の遂行を学習すること が重要であるとしている。従来の階層理論による原理で は，患者が現在利用することができる反射よりも，上位 のレベルの反射を誘発して運動を正常化させることに ある。したがって, 治療者の仕事は患者に適切な刺激を 入力することにあった。しかし，刺激に対寸る反射・反 応によるトレーニングでは画一的なパターンの運動し か生み出さず, いかに機能的な運動へ結びつけるのかと いった問題が起きてくる。

また, 課題指向型アプローチはダイナミカル・システ ムズ理論による運動制御の考え方である。従来の階層理 論では上位の中枢神経系が下位の中枢を支配すること によって正常な運動が制御されると仮定する理論であ る(図3)。しかし, ダイナミカル・システムズ理論では, 特定のシステムが別のシステムを支配するのではなく, すべてのシステムが並列的に機能寸ると考えている。ま た, 階層理論では患者が行う健常者と異なる運動パター ンは「異常運動」といわれるが，「障害による機能の削 減」や「残存システムによる代償」として位置づけてい 


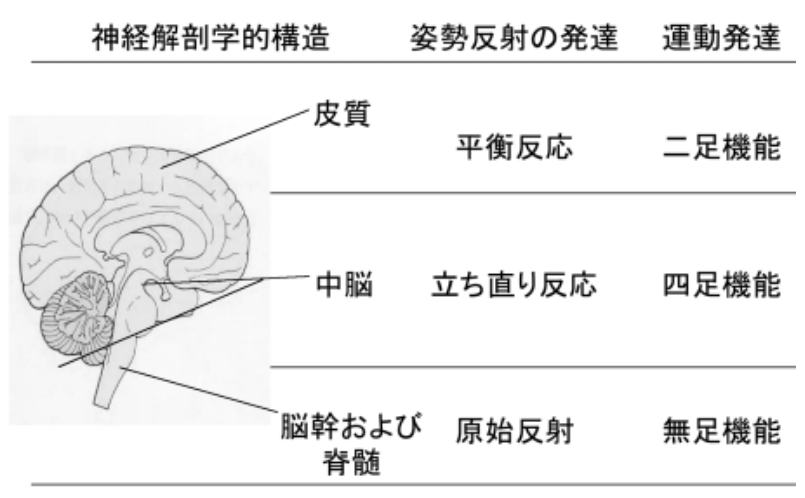

図3階層理論による理学療法の考え方

る。つまり，たとえ代償運動であっても，効率の良いパ ターンを提案することができることが大きな違いとい える。その点では, 階層理論はダイナミカル・システム ズ理論より一世代前の理論であるといえる。

課題指向型アプローチは問題解決を基盤とする介入 理論といわれ，個体と環境および両者を有機的に結びつ ける課題（タスク）から構成されている（図4）。また, 課題指向型アプローチで用いられる評価や治療手技は 特に新しいものではない。いくつかの独自の評価・治療 法もあるが，ほとんどは従来の方法論の応用である。そ のため, 課題指向型アプローチの評価と治療の枠組み は, 従来の方法をダイナミカル・システムズ理論の視点 に沿って再配置したものであり, 遂行能力のレベル, 戦 略のレベル, 機能障害のレベルの3つ要素から構成され ている8)。

題指向型アプローチの治療目標は次の 4 点にまとめ られている。

(1) 潜在的な機能障害の改善と予防

(2) 機能的運動課題の達成のための効果的な戦略の学習

(3) 機能的運動課題を遂行する能力の再獲得

(4) 環境条件が変化しても (3)を応用できる能力の獲得

特徽的な点は, 機能的な能力を改善寸ることや獲得 することに主眼をおいていることである。つまり，機能 障害が残存する場合には, その状態に適した効率的な代 償方法を理論に基づいて提示する。そのため, 治療法と して補装具の選択がしばしば行われている。不幸にして 脳損傷を負った患者に対して, 機能回復のみを求めるの ではなく,残存機能を活用して生活地域内にいかに結び つけるのかを目指している。しかし, 効率の良い代償運 動の指導については, 具体的な言及がなされていないこ となどの問題があげられている。

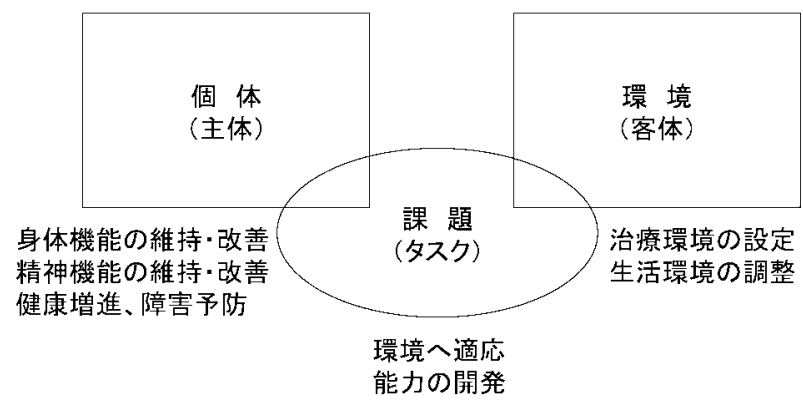

図4課題指向型アプローチの概念

潮見は脳卒中を中心とした中枢神経疾患患者に対す る理学療法について,「理学療法評価で特に重要となる のは，運動機能の実用性の程度を検討することであり， 機能代償の獲得も含め介入によって現状の機能におけ る改善可能性の可否について十分に吟味することであ る」と述べている9)。そのためには, 理学療法評価との 整合性をもつ課題指向型アプローチの展開が必要であ る。

\section{IV.「Motor Relearning Program」による 理学療法理論}

1970年代にCarr and Shepherdらによって提案された運 動再学習プログラム（Motor Relearning Program）では, よりオーソドックスな技能獲得に関する心理学的理論 や効果的な練習方法に関する理論に基づいている10)。彼 らは理学療法の主目的について, 機能的な活動における 運動パフォーマンスを最適化することであると定義し ている。特に, 治療に用いられる課題は環境とのやり取 りのある「具体的課題」が望ましく,「運動のための運 動」のような抽象的な課題は避けるべきであること。リ 八ビリテーションとは, 患者にとって意味のある実際の 日常生活活動を再学習寸ることであり, 実際の生活活動 に結びつかない練習や，いわゆる促通だけを行うもので はないと述べている。この意見は, 背臥位で股関節伸展 の強化運動を行うと, 背臥位における股関節伸展の筋力 は増大寸るが, 立位で股関節を伸展する筋力はわずかに しか発揮できない。つまり, 背臥位と立位では姿勢を安 定させるために働く筋が異なることから, 背卧位でおこ なった練習の成果が，立位で行う運動として「転移」し ないことで説明できる。片麻痺患者に対するトレーニン グとして, 背臥位の姿勢におけるブリッジ運動が一般的 に行われている。歩行という立位姿勢で行われる運動課 
表1 MRPのための 4 つのステップ

\begin{aligned} & \hline ステップ $1:$ 課題の分析 \\ & 観察 \\ & 比較 \\ & 分析 \\ & ステップ $2:$ 欠落している要素の練習 \\ & 練習目標の説明と明確化 \\ & 練習十聴覚と視覚によるフィードバック \\ & 徒手的誘導 \\ & ステップ $3:$ 課題の練習 練習目標の説明と明確化 \\ & 口答指示 \\ & 練習十聴覚と視覚によるフィードバック+徒手的誘導 \\ & 再評価 \\ & 動作の複雑性の拡大 \\ & ステップ $4:$ 様々な環境下でトレーニングを行う機会 \\ & 練習の一貫性 \\ & 自己管理下での練習の設定 \\ & 学習環境の整備 \\ & 家族とスタッフの積極的参加 \end{aligned}

題に対して, 果たしてどの程度の効果がえられるのか, 改めて考え直す必要がある。

また, Carr and Shepherdらの仮説では, 長く理学療法 理論の中心となっていた「神経発達学の原理」に基づい て運動行動をトレーニングするのではなく, 運動技能は ある機能的順序にしたがって獲得される心゙きであると 述べている。したがって，治療における課題について は, 環境とのやり取りのある具体的な課題を取り上げて いる。第2版の「A Motor Relearning Program for Stroke」で は, 運動再学習プログラムの具体例として, 次の7つの 運動課題について述べている。1)上肢機能，2) 口腔顔面 機能，3)ベッドの端での起きあがり，4)バランスの取れ た座位，5)立ち上がりと着座，6)バランスの取れた立位， 7)歩行である。そして，運動再学習のためのセラピスト が行うプログラムとして, 表 1 に挙げるような4つのス テップを挙げている。

ステップ1では，まず患者を観察することが重要であ り, 運動課題の遂行と患者が行う本質的な要素とを比較 し, 欠けている要素についてバイオメカニカル的に分析 を行っている。特に, 運動コントロールについての情報 は, 従来の神経学的評価よりも運動観察によって得られ るというものである。

ステップ2やステップ3では, 欠けている要素の練習に ついて部分練習として行い, ステップ3ではその課題を 全体練習として行う。セラピストは絶えず患者の運動課 題を遂行する過程で, その成功や失敗の原因を分析して
再評価する必要がある。絶えず再評価を行うことで, 分 析と治療決定の適切さをセラピスト自身がフィードバッ クする事が重要であると述べている。

ステップ4では, 患者が治療過程で練習したことを, 治療時間以外にも練習できるようにする方法について 触れている。そのためにも課題は日常生活で行われる課 題となるべきであり，その結果として運動が「転移」さ れると述べている。

また, 各課題に共通してこのプログラムを進める上 で考慮す心゙き点として，以下の3点を挙げている。

(1) 運動課題を一連の全体動作として練習すること

各要素を別々に練習した後，ただちに全体を通した 動作の練習を行うこと。

(2) 患者に対する教示内容に関連したテクニックの利用

目標設定の方法と, どのように目標に到達するかと いうことを指導する。その具体的方法として, 視覚と 聴覚によるフィードバックや徒手誘導が有効である。 (3)運動学習の進め方

より複雑な運動を可能とするためには，徒手誘導や フィードバックを減らし, 速度を変えることを進め ている。

最新の「Stroke Rehabilitation: Guidelines for Exercise and Training to Optimize Motor Skill.」 ${ }^{11)}$ は本邦において翻訳さ れており,「脳卒中の運動療法-エビデンスに基づく機能 回復トレーニング」12) という邦題で出版されている。内 容は, 全面的に書き改めており, 徹底して先行研究の知 
見にその根拠を求めており, エビデンスに基づく理論と 実践が紹介されている。トレーニング内容は，1)バラン ス，2)歩行，3)起立動作と着座動作，4)リーチングと手 の操作に加えて, 機能障害と適応, 筋力トレーニングと 身体コンディショニングにまで広く扱っている。

本書の中では，セラピストによるマン・ツー・マンの 治療法に対する過信を改めることなど，斬新な意見が述 ベられている。なかでも, 非監視でのグループ・トレー ニング・エクササイズを提唱していることは, 我々にとっ ても衝撃的なことであった。運動技能を学習するために 反復練習が必要なことは, 誰でもが知っていることであ り，トレーニングの基本的な原則であるといえる。しか し, その反復練習の場を理学療法士は与えていたであろ うか。従来の臨床場面を振り返ると, 理学療法士の行う 治療テクニックに執着し, 理学療法室でのトレーニング に限定している事が多かった。CarrとShepherdはトレーニ ングの練習量を増すため, 1対1の個別のトレーニングだ けでなく, セラピストの監視から離れたグループ・セラ ピーへ移行してゆくことを積極的に勧めている。セラピ ストが1日に1人の患者に割ける時間は限られており，運 動技能の学習を進めるには不足する治療時間を補う必要 がある。その意味で, 彼らが提唱するグループ・セラピー は一つの重要な方策であるといえる。運動学習理論に限 らず，治療者が治療する場面で可能な動作は, 日常生活 においても転移するためにも, 非監視型のグループ・セ ラピーは計り知れない可能性を持っていると考える ${ }^{13,14) 。 ~}$

\section{V. おわりに}

脳卒中をはじめとする中枢神経障害患者に対する理 学療法について, その理論的背景の変遷に触れた上で, 新たな理学療法介入について紹介した。治療手技の習得 に走りやすいわが国の理学療法士にとって, ファシリ テーションテクニックがもたらした功績は計り知れな い。しかし, 先に紹介した「脳卒中治療ガイドライン」 においても「ファシリテーションは行ってもよいが, 伝 統的なリハビリテーションより有効であるという科学 的根拠はない」と述べられている。また,「Motor relearning programでは, 在院期間が有意に短く, 運動機能やBarthel Indexの改善が大きかった（Ib）」と報告されている15)。 わが国の医療を取り巻く環境は激変しており, 短期間で 最大の効果をあげることが求められている。そのために は, 介入目的を明確にした上で, 高密度で集中的な卜 レーニングを実施し,より実践的な生活を見据えた理学 療法介入が求められている。

\section{引用文献}

1) 日本理学療法士協会 (編) : 理学療法白書, 日本理学療法士 協会，東京， 1995 .

2) 脳卒中合同ガイドライン委員会 HP : 脳卒中治療ガイドライ ン2004. http://www.jsts.gr.jp/jss08.html（閲覧日2007年5月2日）

3) 星 文彦: 運動制御と運動学習. 標準理学療法学一運動療法 学総論. 奈良 勲 (監修), 医学書院, 東京, 2006, pp80-97.

4) 潮見泰藏 : 脳卒中に対する標準的理学療法介入一何を考え, どう進めるか? 文光堂, 2007, 東京, pp2-10.

5) 内山 靖: 環境と理学療法. 医歯薬出版, 東京, 2004, pp1-23.

6) 内山 靖: 中枢神経系における理学療法評価と治療. 中部少 八雑誌，2006, 1: 3-7.

7) 田中 繁（訳）：モーターコントロール一運動制御の理論と 臨床応用一第2版. 医歯薬出版, 東京, 2004, pp3-57.

8) 大橋ゆかり : セラピストのための運動学習 $\mathrm{ABC}$. 文光堂, 東 京, 2004 .

9) 潮見泰藏 : 脳卒中に対する標準的理学療法介入一何を考え, どう進めるか? 文光堂，東京，2007.

10) 横山 嚴 (監訳) : 脳卒中の運動訓練プログラム. 医学書院, 東京, 2004.

11) Carr JH, Shepherd BB: Stroke rehabilitation: guidelines for exercise and training to optimize motor skill. Elsevier, Amsterdam, 2003.

12）潮見泰藏 : 脳卒中の運動療法, 一エビデンスに基づく機能回 復トレーニング. 医学書院, 東京, 2004.

13) 潮見泰藏 : 脳損傷後の機能回復と運動学習. 理学療法科学, 2006, 21: 87-91.

14) 大橋ゆかり：運動学習理論と理学療法の接点. 理学療法科 学, 2006, 21: 93-97.

15) Langhammer B, Stanghelle JK: Bobath or motor relearning programme? A comparison of two different approaches of physiotherapy in stroke rehabilitation: a randomized controlled study. Clin Rehabil, 2000, 14, 361-369. 